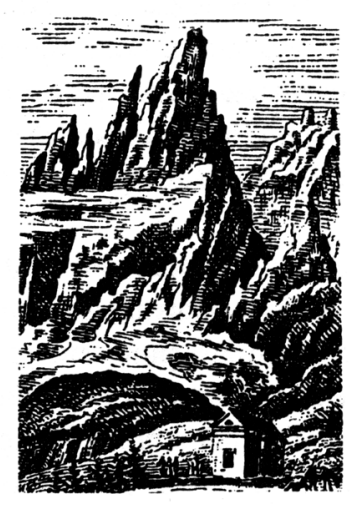

Jarosław Barański

Wrocław

jaroslaw.baranski@umed.wroc.pl

DOI: $10.19195 / 2084-4107.10 .12$

\title{
Piękno gór a higiena duszy i ciała 0 odczycie Henryka Nusbauma w Muzeum im. Tytusa Chałubińskiego
}

Słowa-klucze: Góry, Zakopane, higiena, estetyka, filozofia medycyny

\section{Natura i pedagogika jej piękna}

Henryk Nusbaum, przedstawiciel polskiej szkoły filozofii medycyny na przełomie XIX i XX w., człowiek o pięknym umyśle i szlachetnej duszy, wygłosił w 1896 r. w Muzeum im. Tytusa Chałubińskiego odczyt z zakresu filozofii piękna i wpływu doświadczania piękna zarówno na ciało człowieka, jak i na jego duchowość. W odczycie tym przyjął Nusbaum, że istota ludzka podlega dwóm potężnym siłom - cierpieniu i rozkoszy, lecz one same są formą poczucia piękna i brzydoty. Wzruszenia, jakie udzielają się podczas doświadczania piękna, wpływają — to jego fundamentalna teza — pomyślnie na stany fizjologiczne ludzkiego organizmu:

Fakty zarówno z dziedziny fizjologii, jak i patologii przekonały nas, że wzruszenia moralnie dodatnie (zadowolenie, wesołość itd.) wpły- 
wają pomyślnie na procesy fizjologiczne, na czynności serca, sprawę oddychania, przemianę materii. Co więcej, nawet wobec tak potężnego czynnika chorobotwórczego, jakim jest złowrogi świat drobnoustrojów (bakteryj), czynią nas bardziej odpornymi przez zwiększanie dzielności życiowej naszych tkanek ${ }^{1}$.

Wzruszenia ujemne, wynikające z doświadczania brzydoty (przygnębienie, smutek), upośledzają nas, sprzyjają chorobom i obniżają odporność organizmu. Wzruszenia te, które Nusbaum nazywa częściej moralnymi niż estetycznymi ze względu na tkwiący w nich aspekt emocjonalny, mają swój moment przedmiotowy (bodziec) oraz podmiotowy (układ nerwowy), modyfikują stany fizjologiczne i psychiczne człowieka. Zakres i intensywność tej modyfikacji oparty jest na stałych oddziaływaniach mechanicznych oraz zależny jest również od cech osobniczych. Estetycznie rzecz ujmując, percepcja może być warunkowana nadto przez środki lecznicze i narkotyczne, przyzwyczajenie, przystosowanie oraz przez specyficzny dobór bodźców wzmagających wzruszenia dodatnie.

Źródłem tych ostatnich jest sztuka, będąca wyrazem doskonalenia się człowieka, a jednocześnie doskonaląca go - wzruszenia dodatnie płyną z urzeczywistniania się ideału piękna, a ono samo dzięki mocy unoszenia i uszlachetniania duszy człowieka jest czynnikiem higienicznym, wpływającym na pomyślność i zdrowie człowieka. Dlatego wzruszenia te nigdy nie mogą być zbytkiem ${ }^{2}$ ani w znaczeniu zbyteczności, ani w kontekście kaprysu. Niestety, sztuka nie dla wszystkich jest dostępna, co uznaje Nusbaum za sytuację krzywdzącą ludzi, ponieważ niedostępność ta odmawia możliwości doświadczania piękna i przeżywania pozytywnych stanów psychicznych: „istotną krzywdą ludzkości stanowi nie tylko mnożenie jej cierpień, ale i brak uniesień radosnych"3. Jednakże jest jeszcze jedno piękno, będące przyczyną pożądanych wzruszeń dodatnich — to piękno natury:

Ale jest jedna wielka świątynia z cudownym sklepieniem, wypełniona arcydziełami malowniczości i plastyki, dostępna dla wszystkich świadomych uczestników bytu, nieustanne źródło wrażeń szczytnych — tą świątynią jest wspólne mieszkanie wszystkich ludzi — nasza ziemia ${ }^{4}$.

To przyroda jest obfitym siedliskiem piękna, które należy uczyć się widzieć i odczuwać.

Nusbaum oferuje swoistą społeczną pedagogikę piękna wobec higieny duszy i ciała, czyli zarówno zdrowia fizycznego, jak i psychicznego, gdy postuluje nie tylko ćwiczenie i rozwijanie poczucia piękna w przyrodzie, ale spotęgowanie wrażliwości na jej piękno: „spotęgowanie wrażliwości na piękno natury — jest

${ }^{1}$ H. Nusbaum, Piękno w naturze ze stanowiska higieny duszy i ciała. Odczyt wypowiedziany w Zakopanem na korzyść Muzeum imienia dra Tytusa Chatubińskiego, Warszawa 1897, s. 1-2.

2 Ibidem, s. 7.

3 Ibidem, s. 4.

4 Ibidem, s. 9. 
walnem zadaniem pedagogii”’5. Ta pedagogika piękna ma wiele odcieni: dzięki wychowaniu, po pierwsze, wpłynąć można na młode umysły, aby ową wrażliwość uszlachetniającą duszę i krzepiącą ciało w sobie rozwijały, co uprzedzi ich przed manowcami zrozpaczonego pesymizmu 6 ; nauczyć można, po drugie, „wykrzesywania iskier prawdziwego piękna tam, gdzie organizacja cielesno-duchowa zaniedbana nie znajdzie żadnej rozkosznej podniety, a nawet chorobliwie zwyrodniała czuć będzie niesmak wzruszeń ujemnych"7; wpłynąć zatem należy, po trzecie, na instytucje państwa, które umożliwiałyby młodzieży „wycieczki po kraju dla poznania uroków własnej ojczyzny”, co byłoby „wyrazem prawdziwej troski o dobro i rozwój własnego społeczeństwa, o zdrowie fizyczne i duchowe obywateli, pominąwszy, że jest to jeden z czynników wzmacniających przywiązanie do ziemi ojczystej"8.

Zasada, która przyświeca pedagogice piękna, brzmi następująco: każda jednostka ma „niezaprzeczone prawo dążenia do rozkoszy i szczęścia, oraz obowiązek nie tylko ocierania łez z oczu cierpiącej braci, ale przysparzania jej uśmiechowi wesela"9. Głęboki i szczery humanizm tej myśli Nusbauma sam jest źródłem wzruszenia. Chodzi bowiem społeczną praktykę, obejmującą wszystkie warstwy społeczeństwa, dzięki której pomniejszane są cierpienia i wrażliwość na ujemne wzruszenia, a wzmagana radość i przyjemność życia oraz rozwijana wrażliwość na źródło pozytywnych wzruszeń.

Dlatego należy otworzyć się na doznania uroku natury, tym bardziej że w tej pedagogice piękna tkwi czynnik leczniczy. Choćby krajobraz górski wzniosłym pięknem obdarza człowieka, gdy tylko dozna on potęgi górskich masywów:

spiętrzone masy opoki, tu rozdartej w przepaście, tam ciągnącej się nieskończonymi pasmami warstw pogiętych, gniotących jedna drugą, tam znowu widocznie rozpryśniętej w tysiące brył i odłamów, które tytaniczną pracę wybuchową wulkanów wyrzucone do nieba spadły i leżą jako wieczne pomniki wielkich wysiłków natury... ${ }^{10}$

Ta niesamowita plastyczność Tatr, jeśli jest przedmiotem percepcji, jeśli jest kontemplowana, łączy człowieka z bytem, niwecząc — poprzez wzniosłość, grozę i wielkość krajobrazu — ludzką ciasnotę i sobkostwo. Pobudza ona, twierdzi Nusbaum, do uniesienia ludzkiego ducha, do walki o ideały miłości, mądrości i sprawiedliwości. Wzruszenia, które krajobraz wyzwala, ta siła uczuciowa w ośrodkach nerwowych, przynoszą ukojenie i ulgę, poczucie woli i siły mają moc odciążającą: „To ulżenie ciężaru troski jest zmniejszeniem ujemnych

\footnotetext{
${ }^{5}$ Ibidem, s. 15.

6 Ibidem, s. 14.

7 Ibidem.

8 Ibidem, s. 45.

9 Ibidem, s. 3.

${ }^{10}$ Ibidem, s. 30-31.
} 
wpływów smutku i bólu na sprawę naszego zdrowia"l1. Potęga gór i ich historia powstawania powoduje, że „ogarnia nas głęboka myśl o tem tak potężnem, a tak wzniosłem, tak wymownie pouczającem nas dążeniu natury do tworzenia, do budowania, do nieustającego doskonalenia i poprawiania tego, co już jest spełnionem"12.

Tę siłę wzruszeń estetycznych, sygnalizuje Władysław Matlakowski we Wspomnieniach z Zakopanego: „Upływają godziny, zapomina się o realnym życiu - gdyby nie szczek psa, nie donośne pianie koguta, zatraciłaby się pamięć świata ludzkiego" "13. To odciążenie od trosk codzienności, dystans, poczucie wolności lub uwolnienia, czyli spokój, zadowolenie wewnętrzne, jak pisał Gerszon Lewin w kontekście leczniczego charakteru uzdrowisk, jest koniecznym warunkiem zdrowienia: „Jako lekarz nie mogę się na chwilę nawet pogodzić się z myślą, że można wyzdrowieć lub doznać poprawy bez tego zbawiennego czynnika"14. Nusbaum dodaje: wtedy „osobiste cierpienia i zawody maleją, rany zadane nam przez złość ludzką, zawiść, zdradę goją się, ból łagodnieje"15. To higiena duszy i ciała zapobiegająca chorobom bądź wspomagająca zdrowienie, polegająca na niedopuszczaniu lub usuwaniu tych stanów psychicznych złożonych z wzruszeń ujemnych, które osłabiają organizm i czynią go podatnym na choroby. W odczycie Hygjena umystu i uczucia Nusbaum pisze:

W pewnych postaciach zaburzeń chorobowych, pobyt w miejscowościach szczególnie malowniczych, działa leczniczo nie tylko przez wpływ czystego, krzepiącego powietrza, ale i przez powtarzające się uniesienia estetyczne, tylko ku temu posiadać trzeba odpowiednią wrażliwość ${ }^{16}$.

Jakże więc można nie ulec pięknu Tatr i nie docenić ich higienicznego wpływu, gdy tylko dostrzeże się potęgę sił drzemiących w ich krajobrazie? „[I]leż widziały one zmian na ziemi, ileż przeżyły strasznych kataklizmów, gdy to moce przepotężne poruszały z miejsca i o setki kilometrów przesuwały dziesiątki milionów kilometrów sześciennych twardych skał, łamiąc je, ugniatając i fałdując jak wosk" 17 — pisał Ferdynand Ossendowski. Podziwowi i zachwytowi towarzyszy zarówno uczucie wywyższenia, gdy na szczycie góruje się nad horyzontem, jak i upokorzenia przed majestatem przyrody, a jednocześnie stan oszołomienia, gdy zarazem jest się w niebie i na ziemi. Ta gra uczuć i wzruszeń, twierdzi Nusbaum, czyni organizm ludzki właśnie odporniejszym. Jak to się dzieje? Oto przed oczyma jadących do Zakopanego, relacjonuje Nusbaum, objawiają się Tatry:

\footnotetext{
11 Ibidem, s. 42.

12 Ibidem, s. 32.

13 W. Matlakowski, Wspomnienia z Zakopanego, Warszawa 1901, s. 5.

14 G. Lewin, Wędrówki chorych zagranica, „Krytyka Lekarska” 6, 1902, nr 5.

15 H. Nusbaum, Piękno w naturze..., s. 51.

16 H. Nusbaum, Hygjena umystu i uczucia, [w:] idem, Odczyty i szkice, Warszawa 1908, s. 207.

17 F.A. Ossendowski, Karpaty i Podkarpacie, Poznań 1939.
} 
I wnet pod wpływem tego objawienia ośrodek oddechowy staje się wrażliwszym, zaczynamy oddychać nierównie głębiej, nerwy pobudzają mięsień serca do szybszego i pełniejszego ruchu, krążki krwi raźniej biegnąc przez lepiej przewietrzane płuca, nasycają się obficiej tlenem i podnosi się energia życiowa każdej komórki, każdej tkanki, wibracje drobinek nerwowych potęgują się, czujemy we wszystkich naszych, w całej naszej cielesnej jaźni, jakąś nieopisaną błogą falę podniesionego życia - słowem, jesteśmy przejęci wzruszeniem zachwytu"18.

Wycieczka w góry dostarcza kolejnych wzruszeń wynikających ze zmagania się z naturą, ponieważ wtedy człowiek doznaje ,charakterystycznego zadowolenia z tryumfu nad przeszkodami; wznosząc się raźno po rozesłanych korzeniach drzew lub głazach”"19, a jego percepcja górskiego krajobrazu ma charakter „napiętej ciekawości", zbliżającej do intencji badacza odkrywającego dotąd skrytą tajemnicę natury.

\section{Przesłanki filozoficzno-medyczne idei higienicznego wpływu piękna}

Jan Zamojski twierdzi, iż „Teza, że wszystkie czynności naszego organizmu znajdują się pod wpływem czynników psychicznych, stanowi w koncepcjach przyczyn choroby Henryka Nusbauma myśl najoryginalniejszą"20. Również heurystyczną i inspirującą w takim stopniu, iż jej echo usłyszeć można w estetycznej pracy Heliodora Święcickiego ${ }^{21}$ oraz w myśli filozoficzno-medycznej i praktyce psychiatrycznej Kazimierza Filipa Wizego ${ }^{22}$. Pierwszy w wykładzie O estetyce w medycynie z 1911 r., odwołując się do Karola Libelta, śmiało rozwija tezę Nusbauma, twierdząc, że zasadę warunkującą skuteczność leczniczą konstytuują trzy czynniki: „Piękno, świeżość i porządek są czynnikami estetycznymi, których działalność dobroczynna doniosłego jest znaczenia"23, a sztuka leczenia jest działaniem urzeczywistniającym tę zasadę. Drugi zaś dostrzegł udział piękna w procesie zdrowienia pacjentów, pisząc:

Na choroby ciała zarówno, jak i na choroby ducha, na rozstroje fizyczne i psychiczne, działa piękno przyrody i sztuki. Pobyt wśród natury, widok

${ }^{18}$ H. Nusbaum, Piękno w naturze..., s. 47-48.

19 Ibidem, s. 49-50.

20 J. Zamojski, System filozofii medycyny Henryka Nusbauma, Poznań 2006, s. 140.

${ }^{21}$ H. Święcicki, O estetyce w medycynie, [w:] Księga Pamiątkowa XI Zjazdu Lekarzy i Przyrodników Polskich w Krakowie 18-22 lipca 1911, Kraków 1911.

22 K.F. Wize, Zakres filozofii medycyny, „Archiwum Historji i Filozofji Medycyny” 11, 1931, nr 1; M. Musielak, Kazimierz Filip Wize, [w:] M. Musielak, J. Zamojski, Polska szkoła filozofii medycyny, Poznań 2010, s. 235-251.

23 H. Święcicki, op. cit., s. 74. 
pól, łąk, gór i morza wpływają równie dobrze na powrót do zdrowia, jak muzyka, obrazy, teatr, opera, wyświetlanie, poezja w ,języku bogów”, a nawet choćby tylko proza $\mathrm{w}$, języku ludzi” potocznym i rozrywkowym. Dbają o to uzdrowiska, utrzymując teatry, orkiestry, sprowadzając artystów, wypożyczając książki, fundując galerie ${ }^{24}$.

Postawienie problemu wpływu stanów psychicznych, także powstałych z doznania piękna, na procesy fizjologiczne było możliwe przede wszystkim dzięki przekroczeniu przez Nusbauma dualizmu psychofizycznego. Fundamentalne założenia jego koncepcji opierały się na naturalistycznym monizmie, determinizmie i optymizmie poznawczym: Nusbaum upatrywał „w procesach fizyko-chemicznych instancję rozumienia procesów życiowych, sprzeciwiając się tym samym wszelkim nurtom nawiązującym do neowitalizmu i zakładającym dualizm ontologiczny"25. Dostrzegł te założenia Władysław Szumowski, choć z pewną rezerwą, pisząc, że Nusbauma poglądy mają charakter materialistyczny i mechanicystyczny:

granice pomiędzy nauką o życiu, a nauką o zjawiskach fizyko-chemicznych — jego zdaniem — zacierają się coraz bardziej i z czasem zatrą się zupełnie; w fizjologii panuje niewzruszona konieczność; witalizm, jak i neowitalizm jest teorią błędną; podobnie wszelki dualizm; naukowym jest jedynie monizm materialistyczny ${ }^{26}$.

To stanowisko filozoficzne wyraził jednoznacznie Nusbaum podczas VII Zjazdu Lekarzy i Przyrodników Polskich we Lwowie w 1894 r., podczas którego wygłosił obszerny i niezwykle przekonujący odczyt $O$ wpływie czynności duchowych na sprawy chorobowe. Przesłanką jego koncepcji jest przekonanie, że stany psychiczne są zjawiskami fizjologicznymi, a funkcje fizjologiczne są integralną częścią zjawisk o charakterze duchowym ${ }^{27}$. Te stany psychiczne nazywa Nusbaum wzruszeniami moralnymi, które mają treść emocjonalno-wyobrażeniową. Są to choćby: zaduma, nadzieja, obawa, a także gniew, duma, tęsknota czy też uczucie piękna, litości i miłości i wiele innych. Wesołość, ukazuje Nusbaum, wzmaga bowiem czynność serca, przyśpiesza rytm oddechu, uwrażliwia zmysł wewnętrzny (łaknienie, pragnienie, pożądanie), zwiększa objętość mięśni, które są lepiej ukrwione. Smutek zaś te czynności osłabia, czyniąc mięśnie wiotkimi, zmieniając wygląd, postawę i chód człowieka. Dostrzega jednocześnie wpływ stanów psychicznych na odporność organizmu, na „powstanie, przebieg i zejście najrozliczniejszych form chorobowych bez zmian widocznych i z widocznymi

24 K.F. Wize, op. cit., s. 107.

25 J. Barański, J. Zamojski, Triumwirat piękna, dobra i mądrości - filozofia medycyny Henryka Nusbauma, [w:] Polscy lekarze Żydzi w XIX i XX wieku, red. Z. Podgórska-Klawe, Warszawa 2010, s. 73.

26 W. Szumowski, Filozofia medycyny, Kęty 2007, s. 173-174.

27 H. Nusbaum, O wptywie czynności duchowych na sprawy chorobowe, Warszawa 1894, s. 1. 
zmianami organicznymi” ${ }^{28}$. Nie chodzi jedynie o zmiany powierzchowne, jak siwienie włosów bądź ich wypadanie, ale także o zmiany skórne, w tym zaburzenia czynnościowe, jak biegunka, zaparcia, wymioty, ale i choroby płuc, a może nawet cukrzyca czy bodaj choroby zakaźne. Deklaruje jednocześnie:

jestem od dawna najgorętszym zwolennikiem teorii mikroorganizmów w patologii i najpokorniejszym wielbicielem zasłużonych na tym polu uczonych, chciałem tu tylko zrobić nacisk na jeden jeszcze czynnik, który warunkuje klęskę organizmu w walce $\mathrm{z}$ drobnoustrojami, kiedy czynnik stanowią zaburzenia w stanie psychicznym ustroju, rozszerzając tu pojęcie zaburzenia do każdego zbyt silnego lub ujemnego wzruszenia moralnego ${ }^{29}$.

Z dużą ostrożnością rozważa wykorzystanie sugestii i hipnotyzmu do wyjaśnienia tych wzajemnych wpływów stanów organizmu człowieka.

Odczyt $O$ wptywie czynności duchowych na sprawy chorobowe dedykowany był „Kochanemu koledze i przyjacielowi doktorowi Władysławowi Matlakowskiemu", którego również zalicza się do tych pierwszych, którzy Zakopane przybliżyli światu (Budownictwo ludowe na Podhalu, 1892; Zdobienie i sprzęt ludu polskiego na Podhalu, 1901). Warto wspomnieć, że był to człowiek, jak pisał Zygmunt Kramsztyk, „o wyjątkowo pięknej duszy, człowiek z piersią »skrojoną nie podług miary krawca, lecz Fidyasza «"30, któremu, według Stanisława Witkiewicza, zawdzięczać można ideę góralskiego stylu ${ }^{31}$.

Odczyt Nusbauma w swej wymowie i konstrukcji jest bodaj zadziwiający, ponieważ owo dopuszczenie rozważań nad hipnozą i sugestią nie pojawia się przypadkowo - koncepcja Nusbauma nie była jedyna. Stronnikiem idei wpływu czynności psychicznych na stany fizjologiczne był Julian Ochorowicz. Jak Tytus Chałubiński był „odkrywcą" 32 Zakopanego czy Edward Korniłowicz (członek Towarzystwa Tatrzańskiego, a którego jednego z synów ojcem chrzestnym był Matlakowski) - Rabki, tak Ochorowicz był „odkrywcą” Wisły. Lecz on to właśnie miał w Matlakowskim zajadłego przeciwnika, który odsądzał Ochorowicza od czci i wiary naukowej, upatrując w myśli psychologa jedynie blagę i dziwactwa pseudonaukowe ${ }^{33}$. Otóż, koncepcja Nusbauma była wypowiedzią Ochorowi-

28 Ibidem, s. 17.

${ }^{29}$ Ibidem, s. 28.

30 Z. Kramsztyk, Władystaw Matlakowski, „Gazeta Lekarska” XV, 1895, nr 30, s. 760.

31 S. Witkiewicz, Matlakowski i sztuka ludowa, „Gazeta Lekarska” XV, 1895, nr 30, s. 781-784.

32 Chałubiński zwany był również „królem Tatr” i nie bez przyczyny, jeśli, jak pisze J. Kolbuszewski, „Swą bytność pod Tatrami traktował on nie tylko jako wakacyjną i turystyczną przyjemność, ale także jako ważną do spełnienia misję [...]. To on przyczynił się do cywilizacyjnego wzrostu góralszczyzny i do poprawy marnego wówczas ich bytu"; J. Kolbuszewski, Tytusa Chatubińskiego Sześć dni w Tatrach. Wycieczka bez programu, [w:] Medycyna, literatura, sztuka - przestrzenie, red. W. Wojtkiewicz-Rok, A. Kovtun, J. Barański, Toruń 2009, s. 44.

33 W. Matlakowski, A. Fabian, Dr Fil. J. Ochorowicz i nauka. Przyczynek do historii cywilizacji u nas, „Gazeta Lekarska” VIII, 1888, nr 23, s. 471-503. 
czowskiej idei skojarzeń ideo-organicznych jako podstawy wyjaśnień wpływu czynności psychicznych na stany organiczne człowieka. Nusbaum zdawał sobie sprawę, w jakim kontekście sporów naukowych i ideowych wygłasza swoje stanowisko, bodaj dyskretnie nawiązując do konfliktu Ochorowicza ze środowiskiem lekarzy warszawskich ${ }^{34}$ :

Bardzo wiele światła na sprawę wpływu czynności duchowych na procesy fizjologiczne i patologiczne ustroju rzucają, żywo w ostatnich czasach poruszone, zjawiska sugestii i hipnotyzmu. Nie myślę zapatrywać się z tej strony na obchodzące nas tutaj pytanie, gdyż badania zbyt świeże sfery wzmiankowanych tylko co zjawisk nazbyt zabarwione są jeszcze namiętnością i jednostronnym zapałem, co nadto zamracza trzeźwość i bezstronność sądu. Wolałem przeto fakt wpływu czynności psychicznych na procesy' życiowe tkanek ustroju uwydatnić na szeregu faktów i wniosków niezależnie od kwestii gorączkującej umysły i nadto eksploatowanej przez szarlatanerię z jednej, a bezkrytyczną naiwność z drugiej strony. Rozważanie wreszcie krytyczne badań współczesnych, odnoszących się do sugestii i hipnotyzmu, za daleko by nas tu zaprowadziło. Kwestia ta, sama w sobie zbyt ważna, zasługuje na oddzielne jej traktowanie. Doniosły wpływ czynności duchowych na ogół czynności ustroju, bądź co bądź uwydatniony w ostatnich czasach przez doświadczenia hipnotyczne, zwrócił na siebie uwagę wielu lekarzy, którzy w terapii starają się moment ten uwzględnić ${ }^{35}$.

Jednak stanowisko Nusbauma w sprawie konfliktu Ochorowicza z lekarskim środowiskiem było jednoznaczne negatywne wobec tego ostatniego, szczególnie w kontekście jego wypowiedzi o psychicznych przyczynach cholery ${ }^{36}$.

O ile jednak Nusbaum mówi o wpływie stanów psychicznych na odporność organizmu, to Ochorowicz z rozmachem zakłada, że mogą one mieć wpływ leczniczy. Podstawą tego odziaływania stanów psychicznych na funkcje organizmu są skojarzenia ideo-organiczne: to pierwotnie skojarzenia skurczy mięśni, niezależnych od woli, z wyobrażeniem określonej zmiany wywołanej przez mięśnie, co przez powtarzanie się utrwala. Na mocy prawa odwrotności, pochodzącego z fizyki, wyobrażenie może wywołać ruch pod pewnymi warunkami. Jest to

34 J. Barański, W. Marczak, Julian Ochorowicz i jego konflikt idei, [w:] Zatargi, waśnie, konflikty w perspektywie historycznej i kulturowej, red. K. Łeńska-Bąk, „Stromata Anthropologica” 10, 2015, s. 157.

35 H. Nusbaum, O wptywie czynności duchowych na sprawy duchowe, Warszawa 1894, s. 29.

36 „Tysiące tedy mieszkańców miasta Warszawy — czytelników, przeceniających zapewne wartość tego, co drukowano - dowiaduje się z łamów Kuryjera, że antyseptyka, dezynfekcyja, bakteryje, karbol, siarczan żelaza, chlor, kamera dezynfekcyjna, idealne przestrzeganie czystości, wszystko to głupstwo, oto być pewnym siebie, drwić sobie z zarazy i z przepisów hygijeny publicznej nawet gdy zaraza wybuchnie — w tem cała filozofija!”; H. Nusbaum, Z powodu odczytów Ochorowicza o hipnotyzmie, „Wszechświat” 1888, 7, nr 16, s. 250.

Góry — Literatura — Kultura 10, 2016

(C) for this edition by CNS 
ideoplastia, której podstawą jest właśnie skojarzenie ideo-organiczne ${ }^{37}$, na mocy której „samo wyobrażenie jakieś zmiany funkcjonalnej wystarczy do wywołania tej zmiany" ${ }^{38}$. Może ona mieć charakter ideoplastii wrażeń, ruchów bądź — najistotniejszej - troficznej: „Nie chodzi w niej już o zmianę czuciowo-ruchową, lecz o zmianę istotną, przedmiotową, w funkcjach życiowych, a w szczególności wegetatywnych" 39 .

Ochorowicz w Psychologii i medycynie wprost mówi językiem Nusbauma, iż żadne wzruszenia moralne nie są obojętne dla organizmu, stanowiąc zarówno podnietę zdrowotną, jak i niebezpieczeństwo wywołujące chorobę, szczególnie zagrażając słabym nerwowo: „Odpowiednie hartowanie tych ostatnich może znacznie zmniejszyć patogeniczny wpływ uczuć" ${ }^{40}$. Leczniczy charakter oddziaływania stanów przyjemnych polega więc na żywym biciu serca, szybszym rozgrzaniu ciała, na odrodzeniu zamierających nerwów, popędzeniu leniwych soków ${ }^{41}-$ tu także autosugestia odgrywa istotną rolę. Wzruszenia chorobotwórcze równoważone są wzruszeniami podniosłymi: „Na nich opiera się siła ducha, z nich wypływa wiara, nimi żyje poświęcenie i pod ich znakiem zwyciężają idee"42.

\section{Poetyckość gór, duszy i... zdrowia. Zakończenie}

Ktokolwiek, kto wziął Tatry za przedmiot swojej literackości, zawsze ulegał jakieś niepohamowanej, wręcz nieokiełznanej poetyckości, która nie pozwalała bez porównania, bez metafory czy dalekiego synonimu opisać ich plastyczności. Być może sama natura skłania do poezji, bo, jak pisze Nusbaum, doświadczenie żywego krajobrazu powoduje, że „wtedy widzieć będziemy niebo w kropli rosy, atomy wody zawisłe w powietrzu"43. Dlatego też postuluje w ramach swojej pedagogiki piękna, aby

w młodzieży rozwijać poetyczność, a nawet trochę marzycielstwa. Usposobienie poetyczne sprzyja stanowczo bardziej zdrowiu, aniżeli, jakby to pozornie zdawać się mogło, charakter suchy, pozytywny, rachujący [...]. Jeżeli poezja i miłość piękna kształcą przede wszystkim i wzmacniają ducha; to rozkosze, jakie one dają, krzepią ciało i podniecają dodatnio działalność serca i układu nerwowego ${ }^{44}$.

Nusbaum w odczycie o pięknie natury wygłoszonym w Muzeum Tatrzańskim dowodzi nie tylko poetyckości przyrody i ludzkiego ducha, ale bodaj i samego

37 J. Ochorowicz, Odczyty o magnetyzmie i hypnotyzmie, St. Petersburg 1890, s. 5-6.

38 J. Ochorowicz, Psychologia i medycyna, Warszawa 1916, s. 374.

39 Ibidem, s. 376.

40 Ibidem, s. 315.

${ }^{41}$ Ibidem.

42 Ibidem.

${ }^{43}$ H. Nusbaum, Piękno w naturze..., s. 22.

${ }^{44}$ H. Nusbaum, Hygjena umystu..., s. 206. 
zdrowia, jeśli tej poetyckości przypisuje zbawienny wpływ przedłużający ludzkie życie. $\mathrm{Z}$ wielką pieczołowitością gromadzi spis artystów, którzy dożywali sędziwego wieku. Stąd zapewne i zdrowie musi mieć poetycką naturę - niezwykle delikatną, płochą, lecz właśnie dlatego dającą człowiekowi pełnię jego egzystencji.

\title{
The beauty of the mountains, and the bodily and spiritual hygiene. On Henryk Nusbaum's lecture at the Tytus Chałubiński Museum
}

\begin{abstract}
Summary
In his lecture "Beauty in nature from the point of view of spiritual and bodily hygiene", delivered in 1896 at the Tytus Chałubiński Museum, Henryk Nusbaum described the vividness of the mountain landscape as the object of aesthetic experience, which had a positive impact on the physiological processes of the human body. Emotions stemming from a sense of beauty reduce suffering and pain, bring comfort and relief in everyday worries, strengthen the body and make it more resistant to the causes of disease. Nusbaum calls this beauty of nature, alleviating the negative impact of sorrow and suffering, a hygienic factor, which is sometimes of therapeutic nature. In addition, the experience of the beauty of the mountain landscape is something more than just an aesthetic sensation - it is a premise of contemplation, which elevates human beings morally and prompts them to fight for the ideals of love, wisdom and justice.
\end{abstract}

Keywords: mountains, Zakopane, hygiene, aesthetics, philosophy of medicine 